\title{
Religion and Rationality, Poetry and Philosophy: In Search of the "Axial Breakthrough" in Ancient Greece
}

\author{
Hugh Bowden $^{1}$ (D)
}

Received: 1 June 2016/Accepted: 1 August 2016/Published online: 6 August 2016

(C) The Author(s) 2016. This article is published with open access at Springerlink.com

\begin{abstract}
Axial age theory suggests that a major transformation of thought occurred across several civilisations, including ancient Greece, in the period 800-200 BCE. This paper questions whether any such transformation can be identified in ancient Greece. It focuses on texts associated with "mystery religions" and the works of Presocratic philosophers as potential evidence for transformation. It demonstrates that there was a continuity of thought throughout the period, and that "rationality" was never seen to be in conflict with "traditional religious ideas".
\end{abstract}

Keywords Axial Age · Religion · Poetry · Presocratic · Mystery · Greece · Herodotus · Parmenides

Interest in the idea of the "axial age", and the associated notion of "axial breakthrough" occurring at some point in the first millennium BCE, has been growing in the work of comparative historians and scholars of religion in recent years (Wittrock 2015; Morris 2010, 2015; Bellah 2011). As originally developed by Jaspers (1953), the idea is descriptive rather than explanatory: he argued that between c. 800 and c. 200 BCE parallel intellectual developments could be seen in Greece, Israel, Persia, India and China. Subsequent scholarship has led to the rejection of some of Jaspers' specific arguments, and modification of most of the rest, but the conviction that there was a fundamental shift in thinking across the world in this period has been maintained by axial age theorists. Of the "axial civilisations" identified by Jaspers, it is ancient Greece that has been seen as most clearly embodying the idea of "axial breakthrough", perhaps because the Greek material was the most familiar to the Western-educated scholars who have done most to develop the idea. However, there are clearly differing ideas amongst these

Hugh Bowden

hugh.bowden@kcl.ac.uk

1 King's College London, London, UK 
scholars about what form this breakthrough took in Greece, and when it occurred. Furthermore, it is not clear whether the ancient Greek material supports the interpretations put upon it by axial age theorists. In this paper, I will first discuss some of the proposals made as to what form the axial breakthrough in Greece took, and then consider how far the ancient Greek texts can be seen to support them.

One important contribution to the debate is that of Elkana (1986), who identified "the emergence of second-order thinking" as what characterised the axial breakthrough in Greece. Second-order thinking is "thinking about thinking", and although he acknowledges that this must have existed in all societies, Elkana proposes that systematic second-order thinking was rarer. He makes the point that not all "philosophy" counts as second-order thinking, while some non-philosophical thought may do so. Cosmology, the intellectual area associated with the earlier Presocratics in Greece is best considered as "thinking about the world" and is therefore first-order thinking; on the other hand, considering the range of possible forms of society can be considered to be systematic second-order thinking. It follows from this that whereas the Milesian Presocratic philosophers did not generally engage in second-order thinking, Hesiod, in the myth of the Ages of Man in Works and Days (11. 109-201), did (1986, 48). However, Elkana identifies as the key moment of breakthrough the later part of the fifth century BCE, when, he suggests:

Greek sophists, mystics, and some philosophers discovered more or less simultaneously that man does not have a complete theory of the physical world nor of human society, nor even of man himself, and that all "rational" knowledge had to be complemented by "irrational", i.e. mystical and religious, elements. The resulting tensions between these complementary parts and the ensuing critical dialogue between them - second-order thinking brought about the important breakthroughs (1986, 62-63).

We will return to these issues, but it is important to note at this point that the works of the sophists, and of those he calls "mystics" (whom he identifies as Orphics, and those associated with mystery cults), do not survive and are reported to us by mainly hostile later writers.

For Robert Bellah (2011, 324), "ancient Greece would seem to be the easy case when it comes to the axial age". His major book, Religion in Human Evolution, offers its own grand theory, in which the axial age plays only a part-albeit the climactic part: he claims to offer an evolutionary history of religion from the earliest humans to the axial age. Bellah bases his work on Merlin Donald's scheme of the evolution of human culture, which is made up of three stages, mimetic, mythic, and theoretic (Donald 1991). Bellah identifies the emergence of theoretic culture with the Axial Age:

In the first millennium BCE, theoretic culture emerges in several places in the old world, questioning the old narratives as it reorganizes them and their mimetic bases, rejecting ritual and myth as it creates new rituals and myths, and calling all the old hierarchies into question in the name of ethical and spiritual universalism. The cultural effervescence of this period led to new 
developments in religion and ethics but also in the understanding of the natural world, the origins of science. For these reasons we call this period axial (2011, 19).

Bellah is to some extent indebted to Elkana for his understanding of axial breakthrough, but the main theoretical underpinning of his approach is a particular view of evolution, referred to as "emergentism". "Emergentism" is a metatheoretical notion rather than a theory itself. As one recent account puts it:

Emergentism offers fresh ways to think about contingency... In the history of life, and indeed the history of the planet and the universe, things happen in the context of what has gone on before and the opportunities thereby generated ... Crystals build on crystals, traits build on traits, ideas build on ideas (Goodenough and Deacon 2006, 866).

Its value to Bellah is that it seeks to offer ways of making sense of historical phenomena like human consciousness:

Human minds, deeply entangled in symbolic culture, have an effective causal locus that extends across continents and millennia, growing out of the experiences of countless individuals. Consciousness emerges as an incessant creation of something from nothing, a process continually transcending itself. To be human is to know what it feels like to be evolution happening (Deacon 2003, 306).

When emergentists use the word "evolution", they do not do so in the scientifically rigorous way that characterises Darwinian scholarship. There is a major gulf between the ideas of emergentists such as Bellah, and those who work in the cognitive science of religion, for whom religion can be investigated as a natural phenomenon and a consequence of human biological (i.e. genetic) evolution (Boyer 1994, 2001; Atran 2002). For our purposes, however, Bellah's general theory is less crucial than his interpretation of intellectual development in ancient Greece. Here he differs from Elkana, seeing the Presocratic philosophers, and in particular Xenophanes and Parmenides, as the major forces for intellectual change. He nonetheless shares with Elkana the problem that he locates this change in the thought of authors whose works do not survive or at least survive only in uncertain references and quotations from later authors.

Xenophanes and Parmenides have also been identified as key figures in the development of Greek thought in Richard Seaford's Money and the Early Greek Mind (2004), which Bellah acknowledges, but does not engage with particularly (cf. Seaford 2012). Seaford argues that the introduction of coined money into the Greek world in the sixth century BCE brought with it the notion of exchange value and that this abstracted notion made possible the development of abstract thought more generally in Greece, as exemplified above all by Parmenides. For Seaford, a specific material development, the introduction of coinage, serves the same role as Bellah's rather vaguer notion of the emergence of theoretic culture. Seaford's book does not discuss "axiality", but since coinage is also found in association with supposed 
"axial breakthrough" in China and India, it can be considered as part of the same theoretical approach.

This initial survey has served to introduce some of the major claims put forward by scholars discussing the axial age in the Greek world. It is not easy to sum these claims up, as they are made in different ways by different scholars. However, it is possible to identify two broad aspects of the discussion. One is a claim to identify a change in the nature of thought occurring sometime in the period under discussion; the other is the proposition that this is in part to do with religious understanding. The former may be associated with sophists or with certain Presocratic philosophers; the latter tends to be associated in particular with what are rather loosely referred to as "mystery cults". We may therefore usefully consider these two questions: Did the period see the emergence of new religious doctrines associated with mystery cults (in which we may include in particular "Orphism")? And can we identify a significant change in the nature of thought, in particular about the place of humans in the world?

We must start by recognising that throughout Greek literature, and by extension throughout Greek culture more widely, the relationship between mortals and gods was characterised above all by ignorance. Writers from Homer onwards emphasised that the gods were invisible to mortals; prayers addressed to gods "whoever you might be", are expressions of a genuine uncertainty about what the supernatural powers were like. It was sometimes possible to receive information from the gods, most obviously through divination, but the gods were parsimonious in what they would divulge, and divination was not used to ask questions about the nature of the gods, but to seek advice for immediate concerns (Bowden 2004; Johnston and Struck 2005). This ignorance extended to the issue of what the gods looked like: anthropomorphism was not a belief, but rather a provisional way of talking about the gods.

Furthermore, there was no undisputed source of religious authority in the archaic and classical Greek world: it was a world of small autonomous communities, and those communities were generally led not by monarchs, but by numbers of aristocratic individuals, who were generally in competition with each other. Individual communities could seek some kind of definitive understanding of specific issues to do with the divine through divination, but oracular responses, although they might have persuasive force, were not considered to be divine decrees. Some scholars have suggested that in the later archaic period there emerged a "Delphic theology", promulgated by the oracle of Apollo (Morgan 1990; Murray 1988, 470). This was associated with the famous Delphic maxims including "know thyself", and "nothing in excess", although actual evidence for these phrases being displayed at Delphi does not predate Plato. But even if such a consistent theological line was being disseminated from Delphi, this would not amount to an established orthodoxy. There were many oracular shrines and many forms of divination. Oracles were in competition with each other in the same way that aristocratic would-be leaders, or poets, or indeed communities, were.

In this world, the depictions of the gods in Homer and Hesiod need to be understood as poetic interpretation rather than as any kind of "orthodoxy". Even though Homer and Hesiod, sometimes alongside Orpheus and Musaeus, were 
credited in antiquity with special knowledge or wisdom (Herodotus 2.53; Aristophanes, Frogs 1032-6; Plato, Protagoras 316d), their texts were in no sense religious "scriptures". Nor were they necessarily reflecting universally acknowledged "Greek myths". The close relationship between parts of Hesiod's Theogony and the Bronze Age Hittite Song of Kumarbi has long been recognised (Van Dongen 2011; West 1966, 18-31). While it is generally accepted that the Theogony was composed for a religious occasion, it is nonetheless a poetic text that would have been expected to display innovation, and in this case Hesiod was able to introduce Hittite stories into what purported to be a Greek account of the origin of the cosmos. Such borrowings had probably been occurring over a long period, so the boundary between "Greek" myths and other stories was hard to define. And although there may have been a shared collection of stories about the gods familiar to most Greeks (but rich in potential variation), there was nothing in the ancient Greek world that could be described as a set of "orthodox religious beliefs". Consequently, there was no possibility of a challenge to orthodoxy: Greek ideas about the gods and about religion more generally were always flexible.

This does not rule out the possibility of distinctive religious innovation, a phenomenon claimed to be significant by both Elkana and Bellah. These scholars all identify "mystery religions" as the source for innovation, while remaining rather vague about what they are referring to. The term "mystery cult" tends to refer to two more or less distinct phenomena. First there are festivals associated with certain gods (in particular Demeter) that involved rites of initiation (Burkert 1987; Bowden 2010). Although our information about many of these festivals is limited, the most famous, the Eleusinian Mysteries, was of considerably antiquity. The rituals involved annual secret nocturnal rites held in the sanctuary of Demeter and Kore at Eleusis, near the edge of Athenian territory with possibly several thousand initiates taking part. The most recent scholarship suggests that it is unlikely that this would have been an occasion for the transmission of specific doctrines (Bowden 2010). Of possibly similar antiquity was the ecstatic cult of Dionysus, which involved groups of women (and possibly men) going out from cities to the uncultivated parts of their territory and honouring Dionysus with ecstatic dancing. Again, these are not circumstances which would encourage the transmission of innovative religious notions.

The phenomenon that might be closer to Elkana and Bellah's notion of "mystery religions" as a source for religious ideas is the presence in Greek cities, in particular in the fourth century, of what might be described as "private initiators". We have negative depictions of such men provided by Demosthenes (18.259-60), and at greater length by Plato:

Itinerant priests and seers go to rich men's doors and make them believe that they by means of sacrifices and incantations have accumulated a treasure of power from the gods that can expiate and cure with pleasurable festivals any misdeed of a man or his ancestors ... And they produce a babble of books of Musaeus and Orpheus, the offspring of the Moon and of the Muses, as they affirm, and these books they use in their ritual, and make not only ordinary men but states believe that there really are remissions of sins and purifications 
for deeds of injustice, by means of sacrifice and pleasant sport for the living, and that there are also special initiations, which they call teletai, that deliver us from evils in that other world, while terrible things await those who have neglected to sacrifice (Republic 364b-e).

It is generally thought that the word orpheotelestes, meaning "Orphic initiator", refers to similar men and that this group of initiators can be associated with two interesting texts surviving from the fourth century BCE: the Derveni papyrus (Betegh 2004; Kouremenos et al. 2006) and the so-called Orphic gold tablets (Bernabé and San Cristóbal 2008; Edmonds 2011; Graf and Johnston 2013). These can be described as excavated texts-found in graves in Greece and Southern Italy and Sicily - and although they are not as significant as Chinese excavated texts, they are valuable in being contemporary witnesses for Orphic writing in the fifth or fourth century BCE, that is, texts attributed to the mythical Greek poet Orpheus. The gold tablets have been described as "ritual texts for the afterlife" or "instructions for the netherworld": they consist of shorter or longer texts written on small pieces of gold leaf that presumably were supposed to guarantee those buried with them a better post-mortem experience. Some of the longer texts may be extracted from a katabasis - an account of a journey to the underworld, presumably attributed to Orpheus. Most deal in one way or another with the encounter with underworld powers. The phrase most commonly found on them was the words that the dead souls had to say before they were permitted to drink from the pool of memory, "I am the child of earth and starry heaven". This turns out to be adapted from a line in Hesiod's Theogony (106), describing the race of the Titans as "born from Earth and starry Heaven". Other passages in the Gold Tablets show similarities to ideas in the poetry of Pindar, written in the early fifth century BCE. The Derveni Papyrus is a commentary on another Orphic poem, which is in part at least a theogony. The author of the commentary expresses disappointment with people who seek initiation in state cults (such as the Eleusinian Mysteries) as well as criticising rival initiators. He cites Heraclitus at one point (col. 4), and his arguments show familiarity with the thought of other early philosophers, as well as having verbal echoes of Greek tragedy, but the text is too fragmentary for one to identify any clear innovative thought.

This discussion suggests that "mystery religions" are not a good place to find signs of innovative thinking. The texts that we have are not evidence of any esoteric learning, but rather build on the work of preceding poets (Hesiod, Pindar, Euripides) and share the ideas of contemporary thinkers. This should not surprise us. Burkert identified a series of misconceptions about mystery cults that characterised scholarship of an earlier period:

The first stereotype is that the mystery religions are "late", that they are typical of late antiquity, that is the Imperial or possibly later Hellenistic period, when the brilliance of the Hellenic mind was giving way to the irrational... The second stereotype is that the mystery religions are Oriental in origin, style, and spirit... The third stereotype is that the mystery religions are spiritual, that they are indicative of a basic change in religious attitude, one 
that transcends the realistic and practical outlook of the pagan in a search for higher spirituality $(1987,2-3)$.

One could sum these stereotypes up by saying that "mystery religions" were cast as "other" - they were taken to be whatever it was considered Greek public cult was not, and thus could be claimed as the source of anything new, whether that was the transition to the Middle Ages, or the rise of Christianity, or "axial breakthrough". Burkert goes on to demonstrate that none of these stereotypes helps us understand what mystery cults were and that they should be rejected. We will come back to "mystery cult" in our consideration of Presocratic philosophy, but as part of "traditional" Greek religious experience, not as something separate or new.

As we have noted, the other evidence on which axial age theorists have rested their claims, the writings of the Presocratic philosophers and the sophists, is fragmentary-that is to say it survives mostly through comments and occasional quotations in the work of later writers. This makes it far from easy to identify what these writers actually wrote and argued. Geoffrey Lloyd has pointed out that the whole notion of an identifiable group of thinkers whom we refer to as "Presocratic philosophers" is the creation of Aristotle:

The idea that Thales invented or discovered a new inquiry, "philosophy", goes back to Aristotle, as also does the notion that a more or less continuous development can be traced in certain branches of speculative thought from Thales onward $(1991,128)$.

As a consequence of this, interpretations of what Thales and his supposed successors wrote have been strongly influenced by the agenda of Aristotle and of the later European philosophical tradition (Osborne 2004). Although it may be possible to identify distinctive ideas produced by some of these writers, this must be approached with considerably more caution than some axial age theorists have hitherto shown. It is best to start with a consideration of the nature of Greek thought on the basis of texts that have survived.

I want therefore to turn to the earliest surviving complete prose work in Greek literature, Herodotus' Histories, to explore what Greek thought in the fifth century BCE actually looked like, in order to give a context for the study of earlier, incomplete examples, and to identify some issues relevant to discussions of axial breakthrough. When Herodotus described his own work as histoirai, that is "enquiries", he was using the term in a general way. His work includes much more than what has come to be called history, including ethnography and geography. It has long been recognised that he was more than a simple story-teller. As Rosalind Thomas has put it:

Herodotus' intellectual affinities are perhaps most often connected by scholars with the generation of the "Ionian Enlightenment" of the late sixth century (or earlier). Herodotus mentions Thales and Pythagoras, after all, as well as Hecataeus. The sensitive study by Gould, for instances, sees his important predecessors as Xenophanes, Pythagoras, Heraclitus, the "Milesians", and Hecateus (2000, 6-7, citing Gould 1989). 
To this list can be added the medical writers of the Hippocratic corpus (Lateiner 1986) amongst others.

At the same time, Herodotus engages with the work of poets, most obviously Homer, but also Hesiod and the lyric poets of the early fifth century, Simonides and Pindar (Marincola 2006). He does not suggest that there is always a distinction between the ideas of poets and the ideas of other writers. After describing an experiment carried out by the Achaemenid king Darius I concerning attitudes of different nations to the treatment of the dead, Herodotus concludes, "That is how strongly custom determines these things, and it seems to me that Pindar was correct to write in his poetry saying that custom is the ruler of all things" (3.38). Here Pindar is apparently being used as an authority in an ethnographic discussion. It is clear, however, that Herodotus draws a distinction between his work, as one of prose writing, and those of his poetic predecessors. This is visible in the opening chapters of his Histories, where Herodotus takes stories known to him from poetry (in particular epic), and "demythologises" them, removing all miraculous and divine elements (1.1-4). He thus makes them suitable stories for a work of prose. He is not explicit that this is his purpose, but his successor Thucydides does characterise poets as prone to exaggeration (1.21) and engages in similar exercises in demythologisation (e.g. 1.9-12). There is more that can be said about the complex relationship between the early "historians" and their epic poet predecessors (Rutherford 2012).

The way in which Herodotus and Thucydides engage with their predecessors is also significant. It is well understood that ancient Greece was an "agonistic" society, in which competition played a crucial role. ${ }^{1}$ Iambic and elegiac poetry was composed for and in the competitive atmosphere of the symposium; Attic drama was written for more formal competition at the dramatic festivals in Athens-and tragic poets were willing to send up their rivals and predecessor at times. It is in this context that we should understand the relationship of the earlier prose-writers too. Thucydides criticises statements made by Herodotus, although he never names him; but at the same time he chooses to start his narrative at the precise time and place (Sestos, in $478 \mathrm{BCE}$ ), where Herodotus ends his work: thus he pays homage to his predecessor, and his criticism should be thought of as part of a game, not a fundamental intellectual rejection of the earlier work. In the same way Herodotus' criticism of, for example, earlier geographers (4.36-42) may be understood as an acknowledgement that he is working in the same field.

This discussion has emphasised the "rationality" of Herodotus' work: the extent to which he was engaged in arguments with those characterised as "scientific" such as sophists and medical writers (on which see Thomas 2000). But Herodotus was interested in stories we would classify as myth, and reported stories of divine epiphanies and other miracles (without committing himself to them). Even while he "demythologised" the accounts of poets, he incorporated myths into his own narrative (Baragwanath and de Bakker 2012). Myth and reason in Herodotus are not in competition.

\footnotetext{
1 As most influentially stated by Burckhardt 1998 - the lectures on which the book is based were given in 1898-1902.
} 
What then do the Presocratics look like from the perspective of Herodotus? They would not necessarily stand out as something completely different from other writers. The Milesians offered cosmogonical speculations, but, as long been recognised, their cosmogonies have much in common with Hesiod's Theogony, and probably with other poetic cosmogonies/theogonies attributed to Orpheus (Gregory 2007, 51-4; Gregory 2013, 1-4). "Presocratic" writers like Xenophanes and Parmenides had much to say about the gods, and indeed depicted encounters with them. We find the same combination of religion and rationality in Xenophanes as we do in Herodotus. As Shaul Tor has put it:

We would do well to heed Lloyd's important insight that, when describing the polemical emergence of the "philosophical" from the "traditional", we must never invoke "any talk of a different mentality, a different logic, or a totally different conceptual framework."... Xenophanes' epistemology is, ultimately, no less "religious" than "philosophical" and the two are perfectly compatible (Tor 2013, 278, citing Lloyd 1979).

Indeed, it is not clear what distinguishes the "philosophical" from the "traditional" in this period. We find the same combination of the religious and the philosophical in the work of Parmenides. On the basis of the surviving fragments, we can see that Parmenides' "philosophy" is presented through a poem which describes the poet's encounter with an unnamed goddess. It is this encounter that enables him to understand the true nature of the world, hidden from most people behind the world of appearances (Tor 2015, 22-29). And the encounter is presented as similar to the experience of initiation at a festival like the Eleusinian Mysteries: it is a life-transforming event, that gives a new perspective on the world. ${ }^{2}$ Such lifetransforming encounters are the stuff of other poems, most obviously the Homeric Hymns, and the Homeric Hymn to Demeter in particular, where the goddess eventually reveals to the leaders of Eleusis the rites that will secure them a privileged life. Parmenides' poem has parallels with Hesiod too. He describes at the start of his Theogony (25-8) how the Muses spoke to him, saying that they could show him the truth, just as the Goddess says that she can show the truth to Parmenides (Fr. 1. 52). Xenophanes and Parmenides, like many of the writers grouped together by later tradition into the category of "Presocratic philosophers", were poets and are best understood in this light. They stood alongside Homer and Hesiod, Musaeus and Orpheus, as writers offering accounts of the world. As poets they could claim divine inspiration for what they wrote, but at the same time they could be claimed to be prone to exaggeration and fantasy.

The religious ideas that feed into the work of Parmenides, such as epiphany and initiation, are, it should be noted, part of the mainstream of Greek religious understanding. As we have already noted, Greek religion was not dogmatic and authoritative but, as far back as we can trace, recognised that mortals know little about the gods. To speculate about the nature of the gods and to investigate what they might want through divination, a set of skills that could be learned and transmitted to others was a necessary part of the religious life of ancient Greeks.

\footnotetext{
2 On this interpretation of Eleusis see Bowden 2010.
} 
It is necessary now to draw together the arguments that I have been making. I have argued that there are close links between writings, such as those of the Presocratics in the sixth century BCE, that are characterised as innovative, and those of poets who are generally seen as representing a "traditional" view of the world. This continues to be the case in the fifth century, where we can still find important intellectual affinities between historians and poets (Hornblower 2004). It follows that identifying a significant change in Greek thought that can be claimed as representing the "axial breakthrough" is more difficult than it might appear. Such a transformation in thought is something that has arguably been read onto the ancient Greek material (especially the fragmentary works of the Presocratics and sophists), rather than being clearly there. That is not to deny that there were developments in Greek thought over the period identified by Jaspers as the axial age (c. 800-200 $\mathrm{BCE}$ ); but the important ideas-including awareness of the limitations of human knowledge, which encouraged intellectual enquiry-are present from the earliest surviving Greek literature. At least for the ancient Greek world, axial age theory may itself need re-evaluating.

Acknowledgments This is a revised version of a paper delivered at the international workshop "Comparing 'Axial Breakthrough' in Ancient Civilizations" held at Fudan University on 5-6 December 2015. I am grateful to the organisers and my fellow delegates for the stimulating discussion.

Open Access This article is distributed under the terms of the Creative Commons Attribution 4.0 International License (http://creativecommons.org/licenses/by/4.0/), which permits unrestricted use, distribution, and reproduction in any medium, provided you give appropriate credit to the original author(s) and the source, provide a link to the Creative Commons license, and indicate if changes were made.

\section{References}

Atran, Scott. 2002. In Gods we trust: The evolutionary landscape of religion. Oxford: Oxford University Press.

Baragwanath, Emily, and Mathieu de Bakker. 2012. Myth, truth, and narrative in Herodotus. Oxford: Oxford University Press.

Bellah, Robert. 2011. Religion in human evolution: From the paleolithic to the axial age. Cambridge, Mass: Harvard University Press.

Bernabé, Alberto, and Ana Jiménez San Cristóbal. 2008. Instructions for the netherworld: The orphic gold tablets. Leiden: Brill.

Betegh, Gábor. 2004. The Derveni papyrus: Cosmology, theology and interpretation. Cambridge: Cambridge University Press.

Bowden, Hugh. 2004. Xenophon and the scientific study of religion. In Xenophon and his world, ed. Christopher Tuplin. Stuttgart: Steiner.

Bowden, Hugh. 2010. Mystery cults of the ancient world. London: Thames and Husdson.

Boyer, Pascal. 1994. The naturalness of religious ideas: A cognitive theory of religion. Berkeley: University of California Press.

Boyer, Pascal. 2001. Religion explained: The human instincts that fashion gods, spirits and ancestors. London: Vintage.

Burckhardt, Jacob. 1998. The Greeks and Greek civilisation. London: HarperCollins.

Burkert, Walter. 1987. Ancient mystery cults. Cambridge: Harvard University Press. 
Deacon, Terrence. 2003. The hierarchic logic of emergence: untangling the interdependence of evolution and self-organization. In Evolution and learning: The Baldwin effect Reconsidered, ed. Bruce Weber, and David Depew. Cambridge, Mass: MIT Press.

Donald, Merlin. 1991. Origins of the modern mind: Three stages in the evolution of culture and cognition. Cambridge, Mass: Harvard University Press.

Edmonds, Radcliffe. 2011. The "Orphic" gold tablets and greek religion: Further along the path. Oxford: Oxford University Press.

Elkana, Yehuda. 1986. The emergence of second-order thinking in classical Greece. In The origins and diversity of Axial Age Civilizations, ed. Shmuel Eisenstadt. Albany: SUNY Press.

Goodenough, Ursula, and Terrence Deacon. 2006. The sacred emergence of nature. In The Oxford handbook of religion and science, ed. Paul Clayton. Oxford: Oxford University Press.

Gould, John. 1989. Herodotus. London: Weidenfeld and Nicolson.

Graf, Fritz, and Sarah I. Johnston. 2013. Ritual texts for the afterlife: Orpheus and the Bacchic Gold Tablets, 2nd ed. London: Routledge.

Gregory, Andrew. 2007. Ancient Greek cosmogony. London: Duckworth.

Gregory, Andrew. 2013. The presocratics and the supernatural: Magic, philosophy and science in early Greece. London: Bloomsbury.

Hornblower, Simon. 2004. Thucydides and Pindar: Historical narrative and the world of Epinikian poetry. Oxford: Oxford University Press.

Jaspers, Karl. 1953. The origin and goal of history. London: Kegan Paul.

Johnston, Sarah I., and Peter Struck. 2005. Mantikê: Studies in ancient divination. Leiden: Brill.

Kouremenos, Theokritos, George Parássoglou, and Kyriakos Tsantsanoglou. 2006. The Derveni Papyrus. Firenze: Leo S. Olschki.

Lateiner, Donald. 1986. The empirical element in the methods of the early Greek medical writers and Herodotus: A shared epistemological response. Antichthon 20: 1-20.

Lloyd, Geoffrey. 1979. Magic, reason and experience. Cambridge: Cambridge University Press.

Lloyd, Geoffrey. 1991. Methods and problems in Greek science. Cambridge: Cambridge University Press.

Marincola, John. 2006. Herodotus and the poetry of the past. In The Cambridge companion to Herodotus, ed. Carolyn Dewald, and John Marincola. Cambridge: Cambridge University Press.

Morgan, Michael. 1990. Platonic piety. New Haven: Yale University Press.

Morris, Ian. 2010. Why the west rules-For now: The patterns of history and what they reveal about the future. London: Profile.

Morris, Ian. 2015. Foragers, farmers, and fossil fuels: How human values evolve. Princeton: Princeton University Press.

Murray, Oswyn. 1988. The Ionian Revolt. In Cambridge ancient history, ed. John Boardman, Nicholas Hammond, David Lewis, and Martin Ostwald. Second edition, Vol 4. Cambridge: Cambridge University Press.

Osborne, Catherine. 2004. Presocratic philosophy: A very short introduction. Oxford: Oxford University Press.

Rutherford, Richard. 2012. Structure and meaning in epic and historiography. In Thucydides and Herodotus, ed. Edith Foster, and Donald Lateiner. Oxford: Oxford University Press.

Seaford, Richard. 2004. Money and the early greek mind: Homer, philosophy, tragedy. Cambridge: Cambridge University Press.

Seaford, Richard. 2012. Monetisation and the genesis of the western subject. Historical Materialism 20: $1-25$.

Thomas, Rosalind. 2000. Herodotus in context: Ethnography, science and the art of persuasion. Cambridge: Cambridge University Press.

Tor, Shaul. 2013. Mortal and divine in Xenophanes' epistemology. Rhizomata 1: 248-282.

Tor, Shaul. 2015. Parmenides' Epistemology and the Two Parts of his Poem. Phronesis 60: 3-39.

Van Dongen, E. 2011. The "kingship in heaven"-theme of the Hesiodic Theogony: origin, function, composition. Greek, Roman, and Byzantine Studies 51: 180-201.

West, Martin. 1966. Hesiod Theogony. Oxford: Clarendon Press.

Wittrock, Björn. 2015. The Axial Age in world history. In The Cambridge world history, ed. Craig Benjamin. Cambridge: Cambridge University Press. 
Hugh Bowden is Professor of Ancient History at King's College London, where he has taught since 1989. He is the author of Classical Athens and the Delphic Oracle (Cambridge 2005), Mystery Cults of the Ancient World (London and Princeton 2010) and Alexander the Great: A Very Short Introduction (Oxford 2014). 